\title{
Fluoride Pharmacokinetics in Infancy
}

\author{
JAN EKSTRAND, SAMUEL J. FOMON, EKHARD E. ZIEGLER, AND STEVEN E. NELSON
}

Department of Dental Toxicology: Karolinska Institute, Huddinge. Sweden [J.E.], and Department of Pediatrics. College of Medicine, University of Iow'a, Iow'a City, Iowa 52242 [S.J.F., E.E.Z., S.E.N.]

\begin{abstract}
Fluoride pharmacokinetic data are presented for infants given a fluoride supplement. Seventeen infants participated in a total of 20 studies. On one day, 0.013 mmol $(0.25 \mathrm{mg})$ fluoride was given as a supplement (fluoride supplement study), and on another day a placebo was given (control study). Samples of plasma and urine were collected for $5 \mathrm{~h}$ and analyzed for fluoride. During control studies fluoride intake averaged $0.15 \mu \mathrm{mol} / \mathrm{kg}(2.9 \mu \mathrm{g} / \mathrm{kg})$, and plasma fluoride concentrations ranged from 0.05 to $0.11 \mu \mathrm{mol} / \mathrm{L}(10$ to $20 \mu \mathrm{g} / \mathrm{L})$. In nine instances, the quantity of fluoride excreted in the urine was more than twice that consumed. When the fluoride supplement was given, total fluoride intake averaged $1.93 \mu \mathrm{mol} / \mathrm{kg}(36.6 \mu \mathrm{g} / \mathrm{kg})$. Plasma peak concentration was reached by $30 \mathrm{~min}$ in 14 studies and by $60 \mathrm{~min}$ in six studies. Mean plasma peak fluoride concentration was $3.3 \mu \mathrm{mol} / \mathrm{L}(63 \mathrm{ng} / \mathrm{mL})$. Area under the plasma concentration curve averaged $236 \mathrm{nmol}$. $\mathrm{m}^{-1} \cdot \min \left(4479 \mathrm{ng} \cdot \mathrm{mL}^{-1} \cdot \mathrm{min}\right)$ and was not related to the dose of fluoride. The rate of urinary excretion was significantly correlated with rate of urinary flow. When the dose of fluoride was expressed per unit of body weight, fluoride retention was strongly related to the dose. Retention of the fluoride absorbed from the fluoride dose ranged from $\mathbf{7 5 . 4}$ to $87.6 \%$. Plasma clearance averaged $6.8 \mathrm{~mL} \cdot \mathrm{kg}^{-1} \cdot \mathrm{min}^{-1}$ and decreased significantly with age. Net fractional clearance (renal clearance of the fluoride dose/GFR) averaged $56.7 \%$, which was significantly greater than the $29 \%$ observed during the control studies. The greater percentage retention of fluoride by infants than by adults is probably explained by a greater capacity of the infant to deposit fluoride in hard tissues. (Pediatr Res 35: 157-163, 1994)
\end{abstract}

On the basis of the belief that an adequate intake of fluoride in early life is protective against caries in later life, fluoride supplements are recommended for infants and children living in areas in which the fluoride content of the drinking water is low. However, critical reviews of the evidence $(1-3)$ have led to the conclusion that the effect of fluoride in decreasing the prevalence and severity of dental caries is not primarily systemic but is exerted locally within the oral cavity (4). Because fluoride supplements are quickly cleared from the mouth, the possibility must be considered that they may contribute to enamel fluorosis, which is unquestionably a systemic effect, while providing relatively little protection against dental caries.

During the last 15 or $20 \mathrm{y}$, the dental caries attack rate in the United States has decreased (5) - a decrease has also been observed in a number of other industrialized countries (2). At the same time, the prevalence of enamel fluorosis has increased (6-

Received March 22, 1993; accepted September 24. 1993.

Correspondence and reprint requests: Samuel J. Fomon, M.D., Department of Pediatrics, College of Medicine. University of Iowa, lowa City, IA 52242.

Supported by grants from the Swedish Medical Research Fund, Project No. 6009. Swedish Patent Revenue Fund; NRICGP/USDA Project No. 91-372006182; and NRICGP/USDA Grant 91-37200-6182.
13). As reviewed by Szpunar and Burt (2) and Fomon and Ekstrand (3), little question exists that regular consumption of fluoride supplements increases the risk of enamel fluorosis. However, the relative importance of fluoride supplements and other sources of fluoride intake is unknown.

Although metabolic and pharmacokinetic studies of fluoride throughout infancy and childhood are needed, we have focused our attention on studies of infants. Epidemiologic data provide evidence that, at least under some conditions, fluoride intake during infancy may be a causative factor in the development of fluorosis of the permanent teeth $(14,15)$. Particularly convincing is the report of Forsman (14) concerning 12- and 13-y-old children who had lived since birth in a Swedish community with $1.2 \mathrm{ppm}$ of fluoride in the drinking water. Dental fluorosis was more common among those who, during the first 4 mo of life, had been fed powdered formulas diluted with the tap water than among those who had been breast-fed (and therefore had consumed very small amounts of fluoride).

Whether fluorosis is predominantly the result of the quantity of fluoride absorbed or is influenced to a major extent by mean or peak plasma fluoride concentrations is unknown. Studies of rats indicate that enamel fluorosis may be associated either with high peak plasma concentrations of fluoride $(16,17)$ or with sustained and rather moderate plasma concentrations (17). Little is known about the effect of various infant feeding or supplementation regimens on mean or peak plasma fluoride concentrations.

In recently conducted fluoride balance studies with infants (18), we found that fluoride absorption was high (about $90 \%$ of intake from formula and about $95 \%$ of intake from a fluoride supplement), and that retention of fluoride from a fluoride supplement was approximately $70 \%$ of the dose. The study reported here was undertaken to provide data on plasma fluoride profiles and fluoride pharmacokinetics and additional data on fluoride retention by infants given a fluoride supplement. In the pharmacokinetic studies, we determined plasma clearance of fluoride (disappearance rate of fluoride from plasma) and renal and extrarenal clearance of fluoride. Extrarenal clearance of fluoride is the difference between plasma clearance and renal clearance and is an index to the tissue uptake of fluoride. Fractional urinary excretion of fluoride (urinary excretion of fluoride as a fraction of the amount filtered at the glomerulus) was also determined.

\section{MATERIALS AND METHODS}

Subjects and feedings. The study protocol was approved by the University of Iowa Committee on Research Involving $\mathrm{Hu}$ man Subjects, and written consent was obtained from one or both parents. Seventeen infants, 11 girls and 6 boys, participated in the studies. One girl and two boys were studied twice at different ages; thus, a total of 20 studies were conducted. All participants were considered to be healthy as determined by history and physical examination. Table 1 indicates the gender, age, body weight, and type of feeding of each infant. and the fluoride concentration of the feeding. The designated feeding 
Table 1. Age, body weight, and feeding of study subjects

\begin{tabular}{|c|c|c|c|c|c|}
\hline \multirow[b]{2}{*}{ Subject no. } & \multirow[b]{2}{*}{ Gender } & \multirow[b]{2}{*}{ Age (d) } & \multirow[b]{2}{*}{ Body weight (g) } & \multicolumn{2}{|r|}{ Feeding } \\
\hline & & & & Type* & $\begin{array}{l}\text { Fluoride concentration } \\
(\mu \mathrm{g} / \mathrm{L})\end{array}$ \\
\hline 5013 & $\mathrm{~F}$ & 37 & 5400 & $\mathrm{HM}$ & 7 \\
\hline 4478 & $\mathrm{~F}$ & 47 & 4715 & $\mathrm{MBF}$ & 128 \\
\hline 4258 & $\mathrm{~F}$ & 53 & 4905 & ISPF & 308 \\
\hline 4479 & $\mathrm{~F}$ & 68 & 4585 & $\mathrm{MBF}$ & 55 \\
\hline 3268 & $\mathrm{~F}$ & 74 & 5225 & $\mathrm{MBF}$ & 55 \\
\hline 4362 & M & 102 & 7220 & ISPF & 308 \\
\hline 4326 & $\mathrm{~F}$ & 122 & 6210 & $\mathrm{MBF}$ & 55 \\
\hline 4185 & M & 167 & 8145 & $\mathrm{MBF}$ & 121 \\
\hline 4178 & M & 190 & 9375 & ISPF & 308 \\
\hline 4382 & $\mathrm{~F}$ & 194 & 7610 & $\mathrm{HM}$ & 7 \\
\hline 4432 & $\mathbf{M}$ & 196 & 8640 & ISPF & 308 \\
\hline 4220 & $\mathrm{~F}$ & 203 & 7540 & $\mathrm{MBF}$ & 121 \\
\hline 4456 & M & 205 & 8680 & ISPF & 308 \\
\hline 3269 & $\mathrm{~F}$ & 205 & 7330 & $\mathrm{HM}$ & 7 \\
\hline 4219 & $\mathrm{~F}$ & 213 & 7670 & $\mathrm{MBF}$ & 121 \\
\hline 5007 & $\mathrm{~F}$ & 218 & 9935 & $\mathrm{MBF}$ & 208 \\
\hline 4185 & $\mathbf{M}$ & 354 & 10436 & $\mathrm{CM}$ & 50 \\
\hline 4178 & $\mathbf{M}$ & 371 & 11605 & $\mathrm{MBF}$ & 55 \\
\hline 4379 & M & 408 & 8960 & $\mathrm{CM}$ & 50 \\
\hline 4220 & $\mathrm{~F}$ & 410 & 9665 & $\mathrm{MBF}$ & 90 \\
\hline
\end{tabular}

* HM, human milk (breast-fed infant): MBF, milk-based formula; ISPF, isolated soy-protein-based formula: CM, cow milk.

had been given for at least several weeks before the study was begun. The concentration of fluoride in human milk $(7 \mu \mathrm{g} / \mathrm{L})$ was taken from the literature (19-22). All other fluoride concentrations were determined (see "Fluoride determinations" section).

Study design. Each study was carried out during 2 consecutive days in the Lora N. Thomas Infant Metabolic Unit. On one day, a fluoride supplement was given (fluoride supplement study), and on another day a placebo was given (control study). On the $2 \mathrm{~d}$ of study of an infant, procedures were identical except that in most of the control studies fewer blood specimens were obtained.

Procedures. Infants received their early morning feeding at home. After admission to the metabolic unit and at least $2 \mathrm{~h}$ after the early morning feeding, the infants were given $50 \mathrm{~mL}$ of a $5 \%$ glucose solution by bottle. In the fluoride supplement studies, as soon as the baby voided, a precisely weighed amount (approximately $2.5 \mathrm{~mL}$ ) of a dilute fluoride solution containing $0.013 \mathrm{mmol}(0.25 \mathrm{mg})$ of fluoride was given by syringe directly into the infant's mouth and was followed by two rinses of $5 \mathrm{~mL}$ of $5 \%$ glucose solution. The fluoride solution was prepared by diluting a commercially available fluoride supplement preparation [Pediaflor, Ross Laboratories, Columbus, OH; $0.026 \mathrm{mmol}$ $(1.1 \mathrm{mg})$ sodium fluoride providing $0.026 \mathrm{mmol}(0.5 \mathrm{mg})$ fluoride $/ 1.0 \mathrm{~mL}$ ] $1: 5$ with $5 \%$ glucose solution. In control studies, $2.5 \mathrm{~mL}$ of $5 \%$ glucose solution was given in similar fashion, followed by two $5-\mathrm{mL}$ rinses of $5 \%$ glucose solution. One $\mathrm{h}$ after the administration of the fluoride supplement or placebo, the infant was given breast feeding or formula feeding. The intake of fluoride from this feeding is listed in Table 2 for the control studies and is included as a portion of the total fluoride intake for the fluoride supplement studies (Table 3). Most of the infants were given a second breast feeding or formula feeding toward the end of the 5-h urinary collection period, but fluoride intake from these feedings probably contributed little to fluoride excretion during the collection period and therefore has not been included as a portion of the fluoride intake.

Before obtaining blood samples, we scrubbed the infant's heel with liquid soap, rinsed it twice with distilled water, then warmed it with a pad soaked in warm water. The skin was swabbed with fluoride-free alcohol, dried, and punctured with a disposable blade (Tenderfoot, International Technidyne Corporation, Edi- son, $\mathrm{NJ}$ ). Blood was collected in heparinized tubes free of fluoride. Samples were obtained by heel stick immediately before administration of the placebo solution or the fluoride supplement (time 0 ). In the fluoride supplement studies, additional blood samples were obtained $30,60,120$, and $300 \mathrm{~min}$ after administration of fluoride. In control studies, blood samples were obtained at these same time points in five studies. In five other studies. only two additional samples were obtained, and in the remaining 10 studies no additional blood samples were obtained. Infants were not fed for at least $1 \mathrm{~h}$ after the fluoride or placebo was given. All individual urine voidings were collected from time 0 to and including the time of collection of the first specimen produced after time $300 \mathrm{~min}$. The weight and $\mathrm{pH}$ of each urine sample were determined immediately after the infant voided. and the specimen was stored at $-20^{\circ} \mathrm{C}$ until analyzed for fluoride.

Urine was collected with the infant restrained on a metabolic bed as described Fomon et al. (23) and subsequently modified (24) with respect to collection from female infants. During the period of urine collection, the infant remained under direct observation of a research nurse in the Lora N. Thomas Pediatric Metabolic Unit. Urine volume and $\mathrm{pH}$ were measured within minutes after the voiding, and samples were labeled and stored in a refrigerator until completion of the study.

Fluoride determinations. The fluoride concentration of infant formulas was determined in triplicate by a minor modification of the microdiffusion technique originally described by Taves (25). One $\mathrm{g}$ of the sample was diffused for $6 \mathrm{~h}$ at room temperature in sealed plastic Petri dishes with $2 \mathrm{~mL}$ of $4 \mathrm{~N} \mathrm{HClO}_{4}$ saturated with hexamethyldisiloxane, and the lids were prepared with $50 \mu \mathrm{L}$ of $0.5 \mathrm{~N} \mathrm{NaOH}$. After the sample was diffused, the lids were dried in a dessicator. The dried layer was dissolved with $50 \mu \mathrm{L}$ of $0.5 \mathrm{~N} \mathrm{HCl}$ and $100 \mu \mathrm{L}$ of $0.25 \mathrm{M}$ acetate buffer, $\mathrm{pH}$ 5.0. Fluoride concentration was measured with a fluoride ion specific electrode (Orion, model 9609, Waltham, MA).

The fluoride ion specific electrode was also used for determining fluoride concentration of plasma and urine. To adjust ionic strength and $\mathrm{pH}$, we added one-tenth volume of fluoride-free 7.5 $\mathrm{M}$ acetate buffer, pH 5.0, containing 2\% CDTA (trans-1,2diaminocyclohexane-N,N, $N^{\prime}, N^{\prime}$ tetraacetic acid) to fluoride standards and samples. In the anticipated concentration range. the relative SD of direct fluoride measurement in plasma has been shown to be less than 5\% (26). 
Table 2. Intake, excretion, and plasma concentration of fluoride during control studies*

\begin{tabular}{|c|c|c|c|c|c|c|c|c|c|}
\hline \multirow[b]{3}{*}{ Subject no. } & \multirow{3}{*}{$\begin{array}{c}\text { Fluoride } \\
\text { intake } \\
(\mu \mathrm{g} / \mathrm{kg})\end{array}$} & \multirow{3}{*}{$\begin{array}{c}\mathrm{P}_{\mathrm{F}} \\
(\mu \mathrm{g} / \mathrm{L}) \\
\end{array}$} & \multicolumn{4}{|c|}{ Urine } & \multirow{3}{*}{$\begin{array}{c}\text { GFR }\left(\mathrm{mL} \cdot \mathrm{kg}^{-1}\right. \\
\left.\min ^{-1}\right)\end{array}$} & \multirow{3}{*}{$\begin{array}{c}\mathrm{CR}_{\mathrm{r}}\left(\mathrm{mL} \cdot \mathrm{kg}^{-1}\right. \\
\left.\min ^{-1}\right)\end{array}$} & \multirow{3}{*}{$\begin{array}{c}\mathrm{CR}_{\mathrm{F}} \cdot 100 \cdot \mathrm{GFR}^{-1} \\
(0)\end{array}$} \\
\hline & & & \multirow[b]{2}{*}{$\mathrm{pH}$} & \multirow{2}{*}{$\begin{array}{c}\mathrm{V}_{\mathrm{t}} \\
(\mathrm{mL} / \mathrm{min})\end{array}$} & \multicolumn{2}{|c|}{$\left(U_{\mathrm{F}} \cdot V\right)_{h}$} & & & \\
\hline & & & & & $\left(\mathrm{ng} \cdot \mathrm{kg}^{-1} \cdot \mathrm{min}^{-1}\right)$ & $\left(\mu \mathrm{g} \cdot \mathrm{kg}^{-1} \cdot 5 \mathrm{~h}^{-1}\right)$ & & & \\
\hline 5013 & 0.1 & 17 & 7.36 & 0.33 & 6.1 & 1.85 & 1.67 & 0.36 & 22 \\
\hline 4478 & 1.8 & 16 & 5.71 & 0.27 & 10.0 & 3.01 & 1.70 & 0.63 & 37 \\
\hline 4258 & 4.1 & 12 & 7.08 & 0.45 & 8.3 & 2.49 & 2.01 & 0.69 & 34 \\
\hline 4479 & 1.9 & 20 & 6.52 & 0.44 & 13.1 & 3.92 & 2.02 & 0.65 & 32 \\
\hline 3268 & 1.2 & 11 & 6.86 & 0.20 & 4.4 & 1.34 & 1.84 & 0.40 & 22 \\
\hline 4362 & 10.5 & 15 & 7.06 & 0.36 & 4.7 & 1.40 & 2.04 & 0.31 & 15 \\
\hline 4326 & 1.8 & 15 & 6.31 & 0.82 & 13.5 & 4.06 & 1.89 & 0.90 & 47 \\
\hline 4185 & 2.6 & 17 & 6.00 & 0.49 & 9.4 & 2.84 & 2.56 & 0.56 & 22 \\
\hline 4178 & 7.7 & 16 & 6.55 & 0.58 & 6.4 & 1.93 & 1.62 & 0.40 & 25 \\
\hline 4382 & 0.1 & 17 & 7.21 & 0.57 & 7.4 & 2.23 & 1.38 & 0.44 & 32 \\
\hline 4432 & 7.4 & 14 & 6.62 & 0.28 & 5.0 & 1.50 & 1.34 & 0.36 & 27 \\
\hline 4220 & 2.3 & 16 & 6.74 & 0.70 & 6.4 & 1.92 & 2.25 & 0.40 & 18 \\
\hline 4456 & 7.0 & 13 & 6.80 & 0.70 & 6.5 & 1.96 & 1.65 & 0.65 & 40 \\
\hline 3269 & 0.1 & 10 & 6.72 & 0.77 & 8.2 & 2.46 & 2.13 & 0.63 & 30 \\
\hline 4219 & 0.7 & 16 & 7.06 & 0.20 & 6.2 & 1.84 & 1.72 & 0.38 & 22 \\
\hline 5007 & 4.7 & 12 & 7.42 & 0.42 & 10.1 & 3.03 & 2.40 & 0.84 & 35 \\
\hline 4185 & 0.7 & 17 & 6.36 & 0.82 & 15.5 & 4.66 & 2.03 & 0.91 & 45 \\
\hline 4178 & 0.7 & 19 & 6.34 & 1.13 & 6.7 & 2.02 & 2.23 & 0.35 & 16 \\
\hline 4379 & 1.6 & 15 & 6.75 & 0.75 & 14.5 & 4.36 & 2.58 & 0.97 & 37 \\
\hline 4220 & 1.6 & 12 & 5.36 & 0.67 & 7.6 & 2.27 & 2.03 & 0.63 & 31 \\
\hline Mean & 2.9 & 15.0 & 6.64 & 0.55 & 8.5 & 2.55 & 1.95 & 0.57 & 29 \\
\hline SD & 3.0 & 2.7 & 0.52 & 0.25 & 3.3 & 1.00 & 0.35 & 0.21 & 9 \\
\hline
\end{tabular}

* $P_{F}$, plasma fluoride concentration: $V_{t}$, rate of urinary flow over the 5-h interval; $\left(U_{F} \cdot V\right)$, urinary excretion of fluoride over the 5-h interval: $\mathrm{CR}_{\mathrm{F}}$, renal fluoride clearance.

Table 3. Intake, excretion, and retention of fluoride during fluoride studies*

\begin{tabular}{|c|c|c|c|c|c|}
\hline \multirow[b]{2}{*}{ Subject no. } & \multicolumn{2}{|c|}{ Fluoride intake in $5 \mathrm{~h}$} & \multirow[b]{2}{*}{$\mathrm{T}_{\max }(\min )$} & Plasma fluoride & \\
\hline & $D_{\mathrm{r}}(\mu \mathrm{g} / \mathrm{kg})$ & Total $(\mu \mathrm{g} / \mathrm{kg})$ & & $P_{F \text { max }}(\mu \mathrm{g} / \mathrm{L})$ & $A U C_{F, n e t}(\mu \mathrm{g} \cdot \min / \mathrm{L})$ \\
\hline 5013 & 43.9 & 44.0 & 30 & 58 & 4755 \\
\hline 4478 & 50.5 & 53.8 & 60 & 58 & 4470 \\
\hline 4258 & 48.3 & 56.1 & 60 & 69 & 5640 \\
\hline 4479 & 50.8 & 52.2 & 30 & 72 & 5430 \\
\hline 3268 & 44.7 & 45.7 & 30 & 64 & 4590 \\
\hline 4362 & 33.9 & 44.9 & 60 & 48 & 4410 \\
\hline 4326 & 38.8 & 41.0 & 30 & 73 & 5745 \\
\hline 4185 & 28.9 & 32.6 & 30 & 60 & 2775 \\
\hline 4178 & 25.0 & 34.0 & 30 & 71 & 5198 \\
\hline 4382 & 31.2 & 31.4 & 60 & 58 & 4695 \\
\hline 4432 & 28.0 & 35.4 & 60 & 50 & 3165 \\
\hline 4220 & 32.4 & 36.8 & 30 & 67 & 5130 \\
\hline 4456 & 26.9 & 33.5 & 30 & 49 & 3825 \\
\hline 3269 & 32.3 & 32.4 & 30 & 66 & 5790 \\
\hline 4219 & 30.2 & 31.7 & 60 & 92 & 7725 \\
\hline 5007 & 24.2 & 27.6 & 30 & 60 & 4245 \\
\hline 4185 & 22.4 & 23.1 & 30 & 79 & 5565 \\
\hline 4178 & 20.5 & 21.6 & 30 & 66 & 4260 \\
\hline 4379 & 26.1 & 27.2 & 30 & 48 & 4020 \\
\hline 4220 & 24.2 & 26.9 & 30 & 60 & 4155 \\
\hline Mean & 33.2 & 36.6 & 39 & 63 & 4779 \\
\hline SD & 9.7 & 10.0 & 14 & 11 & 1077 \\
\hline
\end{tabular}

* $D_{F}$, dose of fluoride supplement; $T_{\max }$, time at which peak plasma fluoride concentration was observed: $P_{F \text { max }}$, the peak plasma fluoride concentration; $\mathrm{AUC}_{\mathrm{F}, \mathrm{net}}$, the area under the plasma fluoride concentration curve attributable to the fluoride dose.

Creatinine in urine was determined with a Gilford chemical analyzer (model SBA 300, Ciba Corning Diagnostics, Oberlin, $\mathrm{OH})$ using a modification of the Jaffe method as described in the Gilford manual of procedures.

Pharmacokinetic calculations. In the control studies, the rate of urinary excretion of fluoride $\left(U_{F} \cdot V\right)$ was determined by multiplying fluoride concentration of the urine $\left(\mathrm{U}_{\mathrm{F}}\right)$ by the rate of urine flow (V) for each interval from one urination to the next, beginning with time 0 . The quantity of fluoride excreted in the interval was determined by multiplying the rate of urinary excretion of fluoride by the elapsed time. The rate of urinary excretion for the approximately 5 -h period was determined as the sum of the fluoride excretion in the several intervals divided by the total elapsed time of collection, and was adjusted for body 
weight $\left(\mathrm{ng} \cdot \mathrm{kg}^{-1} \cdot \mathrm{min}^{-1}\right)$ and designated $\left(\mathrm{U}_{\mathrm{F}} \cdot \mathrm{V}\right)_{\mathrm{t}}$. Urinary excretion of fluoride in $5 \mathrm{~h}$ was calculated by multiplying the rate of excretion per minute by $300 \mathrm{~min}$. The adjusted rate of urinary flow for the 300-min period was designated $V_{t}$.

For each infant, urinary excretion attributable to the supplement, $\left(U_{F} \cdot V\right)_{t, \text { net }}$, was calculated as $\left(U_{F} \cdot V\right)_{t}$ observed in the fluoride supplement study minus $\left(U_{F} \cdot V\right)_{t}$ in the control study. Retention of fluoride from the fluoride supplement was calculated as follows: $\operatorname{Ret}_{\mathrm{F} \text {,net }}=\mathrm{D}_{\mathrm{F}} \cdot 0.95-\left(\mathrm{U}_{\mathrm{F}} \cdot \mathrm{V}\right)_{\mathrm{t} \text {, net }}$, where $\mathrm{D}_{\mathrm{F}}$ is the dose of the fluoride supplement and 0.95 is the fractional absorption of fluoride from a fluoride supplement. The factor 0.95 is based on results of $1272-\mathrm{h}$ metabolic balance studies with infants given a fluoride supplement $3 \mathrm{~h}$ after and $1 \mathrm{~h}$ before a formula feeding (18). Under these conditions (the same as in the present study), absorption of fluoride from the fluoride supplement ranged from 91.8 to $98.8 \%$ of supplement intake. Use of the factor 0.95 is therefore unlikely to introduce an important error.

In the fluoride supplement studies, the area under the plasma concentration curve from 0 to $5 \mathrm{~h}$ attributable to the fluoride supplement $\left(\mathrm{AUC}_{\mathrm{F} \text {,net }}\right)$ was calculated using the trapezoidal rule after subtracting the baseline plasma concentration of fluoride from each of the determined plasma concentrations. Plasma clearance of the fluoride dose $\left(C P_{F, \text { net }}\right)$ was calculated as $D_{F} \cdot 0.95 / A U C_{F, n e t}$. Renal clearance of the dose $\left(C_{F, n e t}\right)$ was calculated as $\left(\mathrm{U}_{\mathrm{F}} \cdot \mathrm{V}\right)_{\mathrm{t}, \text { net }} / A U \mathrm{~A}_{\mathrm{F} \text {,net }}$. The extrarenal clearance of the dose of fluoride supplement $\left(\mathrm{CER}_{\mathrm{F} \text {.net }}\right)$ was calculated as the difference between plasma clearance of the dose and the renal clearance of the dose: $C E R_{F, \text { net }}=C P_{F, \text { net }}-C R_{F, \text { net }}(27)$.

GFR was approximated by determining the clearance of creatinine $\left(U_{\text {creat }} \cdot V\right)_{t} / P_{\text {creat }}$, where $\left(U_{\text {creat }} \cdot V\right)_{t}$ is analogous to $\left(\mathrm{U}_{\mathrm{F}} \cdot \mathrm{V}\right)_{l}$, representing the rate of urinary excretion of creatinine during the 5-h period of study, and $P_{\text {creat }}$ is plasma concentration of creatinine. Renal clearance of fluoride $\left(C_{F}\right)$ during the 5-h period was calculated as $\left(\mathrm{U}_{\mathrm{F}} \cdot \mathrm{V}\right)_{k} / \mathrm{P}_{\mathrm{F}}$, where $\mathrm{P}_{\mathrm{F}}$ is plasma fluoride concentration. The rate of urinary excretion of fluoride as a percentage of the rate at which fluoride was filtered through the glomerulus (fractional clearance of fluoride) was calculated as $\mathrm{CR}_{F} \cdot 100 \cdot \mathrm{GFR}^{-1}$

Statistical analysis. The data were summarized using standard descriptive statistics and linear regression with SAS version 5.18 (SAS Institute, Cary, NC).

\section{RESULTS}

Control studies. Fluoride intake from a single feeding of milk or infant formula averaged $0.15 \mu \mathrm{mol} / \mathrm{kg}(2.9 \mu \mathrm{g} / \mathrm{kg})$ (Table 2). The single feeding intake by breast-fed infants was $5.3 \mathrm{nmol} / \mathrm{kg}$ $(0.1 \mu \mathrm{g} / \mathrm{kg})$; for infants fed cow milk or a milk-based formula with fluoride concentration of 2.9 to $10.9 \mu \mathrm{mol} / \mathrm{L}(55$ to $208 \mu \mathrm{g}$ / $\mathrm{L})$, intakes ranged from 36.8 to $136.8 \mathrm{nmol} / \mathrm{kg}(0.7$ to $2.6 \mu \mathrm{g} /$ $\mathrm{kg}$ ); and for those fed an isolated soy protein-based formula with fluoride concentration $308 \mu \mathrm{g} / \mathrm{L}$, intakes ranged from 0.22 to $0.55 \mu \mathrm{mol} / \mathrm{kg}(4.1$ to $10.5 \mu \mathrm{g} / \mathrm{kg})$. Plasma fluoride concentrations ranged from 0.53 to $1.05 \mathrm{nmol} / \mathrm{kg}$ ( 10 to $20 \mathrm{ng} / \mathrm{mL}$ ) and were not correlated with fluoride concentration of the feeding.

Urinary excretion during the 5-h collection period averaged $0.45 \mathrm{nmol} \cdot \mathrm{kg}^{-1} \cdot \mathrm{min}^{-1}\left(8.5 \mathrm{ng} \cdot \mathrm{kg}^{-1} \cdot \mathrm{min}^{-1}\right)$, ranging from 0.23 to $0.82 \mathrm{nmol} \cdot \mathrm{kg}^{-1} \cdot \mathrm{min}^{-1}\left(4.4\right.$ to $\left.15.5 \mathrm{ng} \cdot \mathrm{kg}^{-1} \cdot \mathrm{min}^{-1}\right)$. With the exception of the infants fed isolated soy protein-based formulas, urinary excretion generally exceeded the single feeding intake. The finding that urinary excretion sometimes exceeded intake cannot be explained primarily by the excretion of fluoride from a second feeding given near the end of the 5-h study period. In nine instances, the quantity of fluoride excreted in the urine was more than twice that of the single feeding intake, and urinary excretion of fluoride by the breast-fed infants exceeded intake many fold. For the entire 20 studies, the slope of the regression of 5-h urinary excretion of fluoride on intake was not significantly different from zero $(r=-0.353, p=0.127)$. Urinary $\mathrm{pH}$ ranged from 5.36 to 7.42 ; the rate of urinary excretion of fluoride was not correlated with urinary $\mathrm{pH}(r=-0.258 ; p=0.272)$.

Assuming $90 \%$ absorption of fluoride from formula (18) or milk, the mean quantity of absorbed fluoride was $0.14 \mathrm{mmol} / \mathrm{kg}$ $(2.65 \mu \mathrm{g} / \mathrm{kg})$. Retention of fluoride was $5.3 \mathrm{nmol} / \mathrm{kg}(0.10 \mu \mathrm{g} /$ $\mathrm{kg}$ ), or $3.5 \%$ of the quantity absorbed. Retention of fluoride during the 5-h study period was strongly correlated to intake of fluoride (Fig. 1, $r=0.956, p<0.001$ ).

GFR averaged $1.95 \mathrm{~mL} \cdot \mathrm{kg}^{-1} \cdot \mathrm{min}^{-1}$ (Table 2). Renal clearance of fluoride (mean, $0.57 \mathrm{~mL} \cdot \mathrm{kg}^{-1} \cdot \mathrm{min}^{-1}$ ) was not related to urinary $\mathrm{pH}$ or to rate of urine flow $\left(\mathrm{mL} \cdot \mathrm{kg}^{-1} \cdot \mathrm{min}^{-1}\right)$. Fractional renal clearance of fluoride averaged $29 \%$ and did not increase with increasing age.

Fluoride supplement studies. Data from the fluoride supplement studies are summarized in Tables 3 and 4 and Figure 2. The mean quantity of fluoride provided by the supplement was $1.75 \mu \mathrm{mol} / \mathrm{kg}(33.2 \mu \mathrm{g} / \mathrm{kg})$, and the mean total fluoride intake (intake from supplement plus single feeding) was $1.93 \mu \mathrm{mol} / \mathrm{kg}$ $(36.6 \mu \mathrm{g} / \mathrm{kg}$ ) (Table 3). Plasma fluoride concentration increased after administration of the fluoride supplement (Fig. 2). Peak plasma concentration was reached by $30 \mathrm{~min}$ in 14 studies and by $60 \mathrm{~min}$ in six studies (Table 3), and in no instance was the concentration in plasma greater at $120 \mathrm{~min}$ than at $60 \mathrm{~min}$. The average peak fluoride concentration $\left(\mathrm{P}_{\mathrm{F} \text {.max }}\right)$ was $3.32 \mu \mathrm{mol} / \mathrm{L}$ $(\mathrm{SD}, 0.58 \mu \mathrm{mol} / \mathrm{L})(63 \mu \mathrm{g} / \mathrm{L}: \mathrm{SD}, 11 \mu \mathrm{g} / \mathrm{L})$. Net area under the plasma concentration curve averaged $235.7 \mathrm{nmol} \cdot \mathrm{mL}^{-1} \cdot \mathrm{min}$ $\left(4479 \mu \mathrm{g} \cdot \mathrm{L}^{-1} \cdot \mathrm{min}\right)$ and was not related to the dose (micromoles per kilogram) of fluoride.

Urinary excretion of fluoride, $\left(\mathrm{U}_{\mathrm{F}} \cdot \mathrm{V}\right)_{t}$, averaged $25.5 \mathrm{ng}$. $\mathrm{kg}^{-1} \cdot \mathrm{min}^{-1}$ or $7.65 \mu \mathrm{g} \cdot \mathrm{kg}^{-1} \cdot 5 \mathrm{~h}^{-1}$ (Table 4), values approximately three times those observed in the control studies. The rate of urinary excretion of fluoride was significantly correlated with rate of urine flow $(r=0.597 ; p=0.006)$ but not with urinary $\mathrm{pH}(r=0.144 ; p=0.544)$. When the dose of fluoride was expressed per unit of body weight, net fluoride retention (micrograms per kilogram) was strongly related to the dose (Fig. 1. $r=0.995 ; p<0.001)$. However, because the same total quantity of fluoride was administered as a supplement to all infants, the variation of intake expressed as micromoles per kilogram merely reflected the effect of differences in body weight. The fluoride dose per unit of body weight was therefore inversely correlated with age, and it is impossible to distinguish between the effects of body size (or age) and dose (micromoles per kilogram) on the relationship demonstrated in Figure 1.

Fluoride excretion attributable to the dose of fluoride supplement $\left(\mathrm{U}_{\mathrm{F}} \cdot \mathrm{V}\right)_{\mathrm{t}, \mathrm{net}}$ averaged $5.1 \mu \mathrm{g} \cdot \mathrm{kg}^{-1} \cdot 5 \mathrm{~h}^{-1}$-i.e. $7.65 \mu \mathrm{g} \cdot \mathrm{kg}^{-1}$. $5 \mathrm{~h}^{-1}$ (Table 4) minus $2.55 \mu \mathrm{g} \cdot \mathrm{kg}^{-1} 5 \mathrm{~h}^{-1}$ (Table 2). Assuming $95 \%$ absorption of the fluoride supplement (18), retention of fluoride from the supplement as a percentage of the quantity

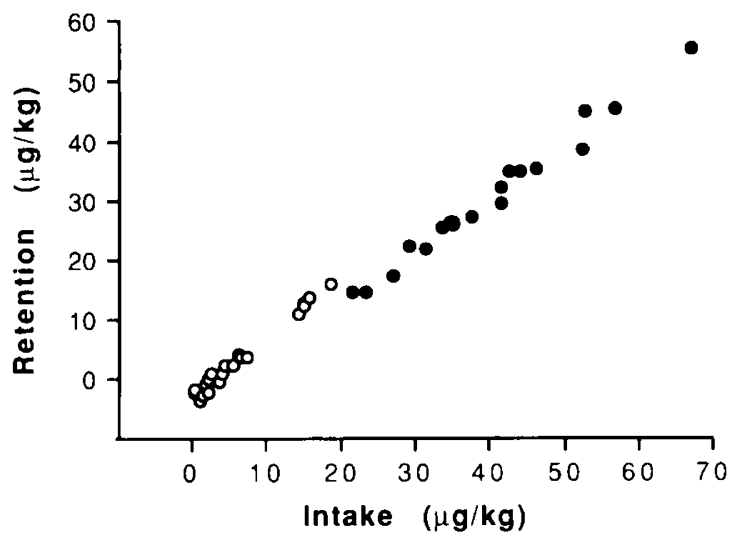

Fig. 1. Relationship of retention of fluoride to intake of fluoride during the 5-h study period $(r=-0.954, p<0.05)$. Each open circle indicates the result of one control study, and each black dot indicates the result of one fluoride supplement study. 
Table 4. Pharmacokinctic indice's after fluoride suppleme'mation*

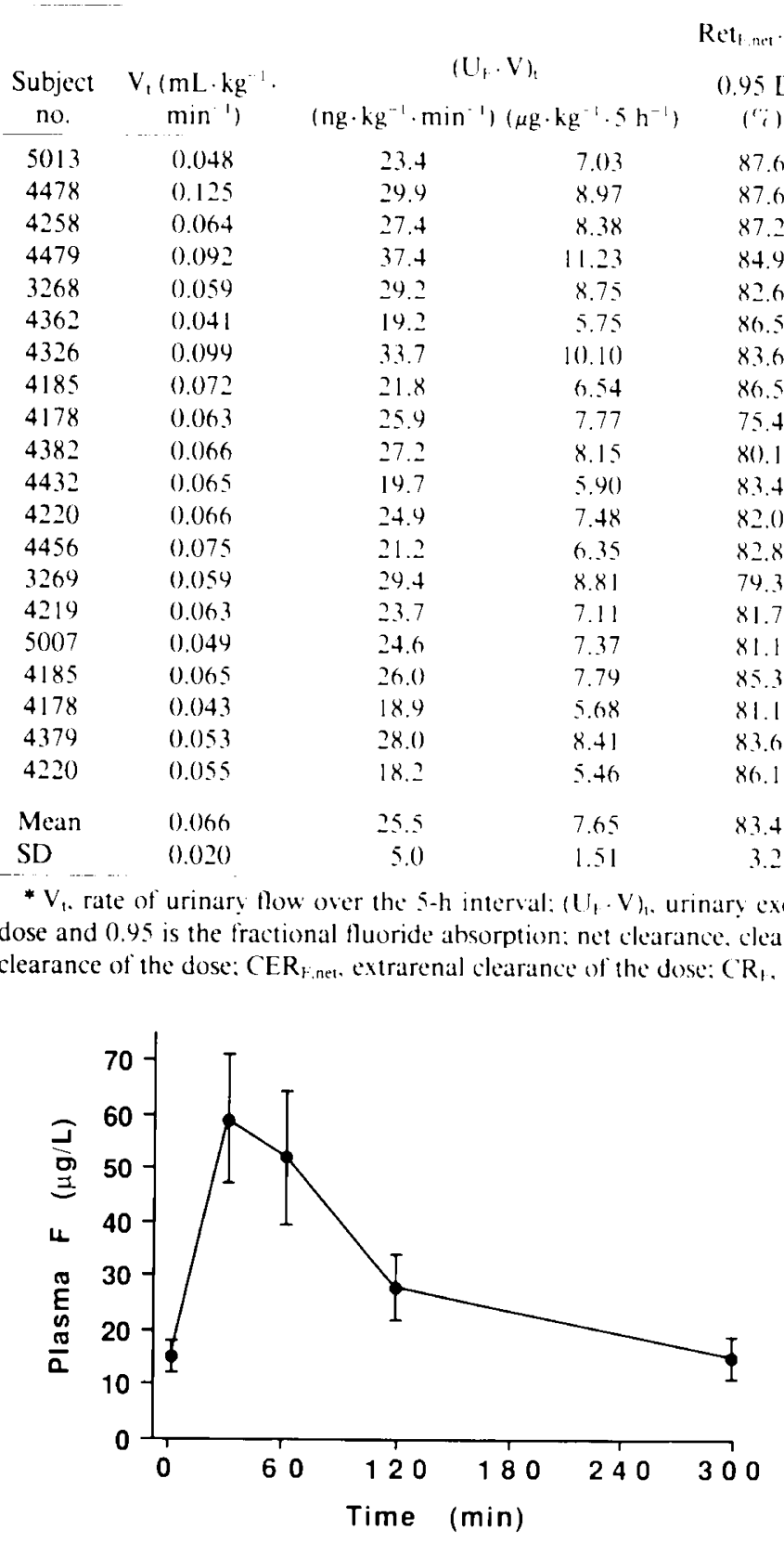

Fig. 2. Mean plasma fluoride concentrations before and at 3(), 60). 120 and 300 min after administration of a 0.25 fluoride supplement. l'ertical line's include \pm 1 SD.

absorbed $\left(\right.$ Ret $\left._{\text {Fet }} \cdot 100 / 0.95 \cdot D_{1}\right)$ varied from 75.4 to $87.6 \%$ of the dose, with a mean of $83.4 \%$ (Table 4 ).

Plasma clearance of the fluoride dose $\left(C P_{\mathrm{F} \text { net }}\right)$ averaged 6.8 $\mathrm{mL} \cdot \mathrm{kg}^{-1} \cdot \mathrm{min}^{-1}$ (Table 4$)$ and decreased significantly with age $(r$ $=-0.685, p<0.001)$ and with body weight $(r=-0.702, n<$ 0.001 ). However, the study was not designed to explore the effects of age or body size on plasma clearance, and further study of these relationships will be necessary.

Renal clearance of the fluoride dose. $C R_{\text {f.net }}$ (mean. $1.1 \mathrm{~mL}$. $\left.\mathrm{kg}^{-1} \cdot \mathrm{min}^{-1}\right)$, also decreased significantly with age $(r=-0.603, p$ $=0.005)$ and was inversely correlated with body weight $(r=$ $-0.543, p=0.013$ ). GFR (data not shown) averaged $1.96 \mathrm{~mL}$. $\mathrm{kg}^{-1} \cdot \mathrm{min}^{-1}$, a value similar to that observed in the control studies (Table 2). Net fractional renal clearance $\left(C_{\text {F net }} \cdot 100 / \mathrm{GFR}\right)$ averaged $56.7 \%$ (Table 4 ), a value significantly greater (paired $t$ test. $p<0.001$ ) than the $29 \%$ observed during the control studies. Net fractional renal clearance decreased significantly $(r=$

\begin{tabular}{|c|c|c|}
\hline Vet clearance & & \\
\hline $\begin{array}{l}\left(R_{\mathrm{k} n \mathrm{nc}}(\mathrm{ml})\right. \\
\left.\mathrm{kg}^{-1} \cdot \min { }^{1}\right)\end{array}$ & $\begin{array}{c}\text { CFR } R_{\text {net }}(\mathrm{mI} \\
\left.\mathrm{kg}^{-} \cdot \min ^{-1}\right)\end{array}$ & $\begin{array}{l}(\mathrm{iFR} \\
(\mathrm{i})\end{array}$ \\
\hline 1.0 & 7.7 & 80.4 \\
\hline 1.3 & 9.4 & 65.0 \\
\hline 1.1 & 7.1 & $6,4.1$ \\
\hline 1.4 & 7.5 & 72.1 \\
\hline 1.6 & 7.6 & 59.2 \\
\hline 1.0 & 0.3 & 45.4 \\
\hline 1.0 & 5.3 & 59.7 \\
\hline 1.3 & 8.6 & 57.3 \\
\hline 1.1 & 3.4 & 68.1 \\
\hline 1.3 & 5.1 & 75.4 \\
\hline 1.4 & 7.0 & 55.5 \\
\hline 1.1 & 4.9 & 59.9 \\
\hline I.1 & 5.5 & 64.6 \\
\hline 1.1 & 4.2 & 60.1 \\
\hline 0.7 & 3.1 & 32.6 \\
\hline 1.0 & 4.4 & 41.7 \\
\hline 0.6 & 3.3 & 29.1 \\
\hline 0.9 & 3.7 & 459 \\
\hline 1.0 & 5.2 & 46.0 \\
\hline 0.8 & 4.8 & 46.9 \\
\hline 1.1 & 5.7 & 56.7 \\
\hline 0.3 & 1.9 & 13.8 \\
\hline
\end{tabular}


single feeding plus the supplement ranged from 21.6 to $67.4 \mu \mathrm{g} /$ $\mathrm{kg}$. The strongly positive correlation between urinary excretion of fluoride and fluoride intake during the fluoride supplement studies was in sharp contrast to the lack of correlation in the control studies. Both in the control studies and in the fluoride supplement studies, fluoride retention was strongly correlated with fluoride intake (Fig. 1).

In the control studies, mean plasma fluoride concentrations did not reflect intake, and significant increases above the baseline plasma fluoride concentration were not observed after feeding. The failure to demonstrate an effect of fluoride intake on plasma fluoride concentration is probably related to the relatively low intakes of fluoride. Many infants in the United States consume much greater quantities of fluoride-approximately $5.26 \mu \mathrm{mol}$. $\mathrm{kg}^{-1} \cdot \mathrm{d}^{-1}\left(100 \mu \mathrm{g} \cdot \mathrm{kg}^{-1} \cdot \mathrm{d}^{-1}\right)$ from concentrated liquid formulas diluted with fluoridated water and $7.89 \mu \mathrm{mol} \cdot \mathrm{kg}^{-1} \cdot \mathrm{d}^{-1}(150 \mu \mathrm{g}$. $\mathrm{kg}^{-1} \cdot \mathrm{d}^{-1}$ ) from powdered formulas diluted with fluoridated water (3). For infants fed five times daily, these intakes amount to approximately 1.05 to $1.58 \mu \mathrm{mol} / \mathrm{kg}$ (20 to $30 \mu \mathrm{g} / \mathrm{kg}$ ) in each feeding. The present study provides no data on the mean or peak plasma fluoride concentrations experienced by such infants.

Fractional renal clearance of fluoride in our control studies averaged $29 \%$ (Table 2), a value intermediate between the values of $20 \%$ and $34 \%$ reported by Schiffl and Binswanger $(31,32)$ in two studies of adult subjects but less than the $40 \%$ reported by Spak et al. (34) for children and adolescents from 4 to 18 y of age. Considerably greater values were observed in a study of two normal adults (33). In all of these studies. GFR was determined with the inulin clearance method, whereas we used the creatinine clearance method. In the study by Järnberg et al. (33), fractional clearance of fluoride was not remarkably different in control (mean, $75 \%$ in eight periods of observation) and fluoride supplement studies (mean, $79 \%$ in 12 periods). In our fluoride supplement studies, fractional renal clearance of fluoride $(56.8 \%$ of intake) was significantly greater than in control studies. We have no explanation for this difference.

In our fluoride supplement studies, the infrequency of blood sampling made it impossible to determine the time at which the peak plasma concentration of fluoride was reached. Nevertheless, in at least some of the infants, peak plasma concentration had not been reached by $30 \mathrm{~min}$ after administration of the supplement. By contrast, in studies of adults (28), peak plasma concentration was regularly achieved by $30 \mathrm{~min}$ after administration of the supplement. The longer time required to reach peak plasma concentration by the infants than by the adults may merely reflect the longer period of fasting by the adult subjects $(12 \mathrm{~h}$ before and $3 \mathrm{~h}$ after the time of administration of the supplement).

Neither the peak plasma concentration of fluoride nor the area under the plasma fluoride concentration curve attributable to the fluoride dose was correlated with fluoride intake. Failure to demonstrate these correlations is probably explained by the relatively small range of fluoride intakes and the considerable individual variability. When adult subjects were given widely differing doses of fluoride ranging from approximately 0.12 to $0.52 \mathrm{mmol}$ ( 3 to $10 \mathrm{mg}$ ), the area under the plasma concentration curve in a specified subject was greater when the fluoride dose was greater, but between subjects at the same fluoride intake there was considerable variability in the area under the plasma concentration curve $(27,28)$.

A significant correlation between renal clearance of fluoride and urinary $\mathrm{pH}$ has been demonstrated in studies of adult subjects $(29,30,33)$. Presumably, reabsorption of fluoride from the renal tubules occurs predominantly by diffusion of nonionic hydrogen fluoride, and the lower the urinary $\mathrm{pH}$ the greater the percentage of fluoride in the form of hydrogen fluoride (29). Our failure to find a correlation between renal clearance of fluoride and urinary $\mathrm{pH}$ may be because our study, in contrast to the studies of adults, was not designed to explore this relationship. and other variables may have obscured the effect of urinary $\mathrm{pH}$
In the fluoride supplement studies but not in the control studies, we found a significant correlation between renal clearance of fluoride and rate of urinary flow, a relationship that has been observed in adult subjects under some $(27,29,30,32-34)$ but not all (30) conditions.

Both in the control studies and in the fluoride supplement studies, retention of fluoride was strongly correlated with fluoride intake (Fig. 1). Retention of fluoride from the fluoride supplement was $79 \%$ of intake. This value is not remarkably different from the $73 \%$ of intake determined in other infants by $72-\mathrm{h}$ balance studies (18) in which the dose of fluoride supplement was given in a similar temporal relationship to feeding.

Retention of fluoride from the dose of supplement, when expressed as percentage of the quantity of fluoride absorbed from the dose, is the same as extrarenal clearance of the fluoride dose expressed as a percentage of plasma clearance of the dose. Our finding that mean retention of fluoride was $83.4 \%$ of the quantity of fluoride absorbed from the dose of supplement (Table 3 ) may be compared with the finding in adults that mean extrarenal clearance of fluoride from a dose of supplement given to adults was $55.3 \%$ of plasma clearance of the dose (29). The difference is statistically significant ( $t$ test, $p=<0.001$ ). Similarly, the value in infants for retention of fluoride expressed as percentage of absorbed fluoride $(83.4 \%)$ can be compared with results of a study of normal adults in which $3 \mathrm{mg}$ of fluoride (about $45 \mu \mathrm{g}$ / $\mathrm{kg}$ ) was infused intravenously over a period of $30 \mathrm{~min}(27)$. Urinary excretion during the next $24 \mathrm{~h}$ averaged $42 \%$ of intake. indicating that retention of fluoride was $58 \%$ of the quantity infused. The greater percentage retention of absorbed fluoride by infants than by the adults is probably explained primarily by a greater capacity of the infant to deposit fluoride in hard tissues (36).

\section{REFERENCES}

1. Thylstrup A 1990 ) Clinical evidence of the role of pre-eruptive fluoride in caries prevention. J Dent Res 69 (spec iss):742-750

2. Szpunar SM. Burt BR 1992 Evaluation of appropriate use of dietary Ruoride supplements in the US. Community Dent Oral Epidemiol 20:148-154

3. Fomon SJ, Ekstrand J 1993 Fluoride. In: Fomon SJ, Nutrition of Norma Infants. Mosby-Year Book. St. Louis, 1993. pp 299-310

4. Ekstrand J. Spack C-J. Vogel G 1990 Pharmacokinetics of fluoride in man and its clinical relevance. J Dent Res 69:550-555

5. Brunelle JA Carlos JP 1990 Recent trends in dental caries in U.S. children and the effect of water fluoridation. J Den Res 69 (spec iss): 723-727

6. Driscoll WS, Horowitz HS, Meyers RJ. Heifetz SB, Kingman A, Zimmerman ER 1986 Prevalence of dental caries and dental fluorosis in areas with negligible, optimal, and above-optimal fluoride concentrations in drinking water. J Am Dental Assoc 113:29-33

7. Segreto VA. Camann D. Collins EM, Smith CT 1984 A current study of mottled enamel in Texas. J Am Dent Assoc 108:56-50

8 . Leverett D 1986 Prevalence of dental fluorosis in fluoridated and nonfluoridated communities-a preliminary investigation. J Public Health Dent 46:184-187

9. Pendrys DG. Katz RV 1989 Risk of enamel fluorosis associated with fluoride supplementation, infant formula, and fluoride dentrifice use. Am J Epidemiol 130:1199-1208

10. Pendrys DG. Stamm JW 1990 Relationship of total fluoride intake to beneficial effects and enamel fluorosis. J Dent Res 69 (spec iss):529-538

11. Szpunar SM. Burt BA 1988 Dental caries, fluorosis, and fluoride exposure in Michigan schoolchildren. J Dent Res 67:802-806

12. Kumar JV. Green EL. Wallace W. Carnahan T 1989 Trends in dental fluorosis and dental caries prevalences in Newburgh and Kingston. NY. Am J Public Health 70:565-569

13. Ismail AI, Brodeur J-M, Kavanagh M. Boisclair G. Tessier C. Picotte L 1990 Prevalence of dental caries and dental fluorosis in students, $11-17$ years of age, in fluoridated and non-fluoridated cities in Quebec. Caries Res 24:290297

14. Forsman B 1977 Early supply of fluoride and enamel fluorosis. Scand J Dent Res 85:22-30

15. Walton JL. Messer LB 1981 Dental caries and fluorosis in breast-fed and bottle-fed children. Caries Res 15:124-137

16. Angmar-Mảnsson B, Ericsson Y, Ekberg O 1976 Plasma fluoride and enamel fluorosis. Calcif Tissue Res 22:77-84

17. Angmar-Månsson B. Whitford GM 1982 Plasma fluoride levels and enamel fluorosis in the rat. Caries Res 16:334-339

18. Ekstrand J. Ziegler EE. Nelson SE. Fomon SJ 1993 Absorption and retention of dietary and supplemental fluoride by infants. Adv Dent Res (in press) 
19. Ekstrand J, Boreus LO, De Chateau $P$ [98 1 No evidence of transfer of thuoride from plasma to breast milk. BMJ 283:761-762

20. Esala S, Vuori E, Helle A 1982 Effect of maternal fluorine intake on breast milk fluorine content. Br J Nutr 48:201-204

21. Spak C-J, Hardell LI, De Chateau P 1983 Fuoride in human milk. Acta Paediatr Scand 72:699-70!

22. Ekstrand J, Hardell LI, Spak C-J 1984 Fluoride balance studies on infants in a 1-ppm-water-fluoride area. Caries Res 18:87-92

23. Fomon SJ, Thomas LN, Jensen RL, May CD 1958 Determination of nitrogen balance of infants less than 6 months of age. Pediatrics 22:94-100

24. Fomon SJ 1960 Comparative study of adequacy of protein from human milk and cow's milk in promoting nitrogen retention by normal full-term infants. Pediatrics 26:51-61

25. Taves DR 1968 Determination of submicromolar concentrations of fluoride in biological samples. Talanta 15:1015-1023

26. Ekstrand J 1977 A micromethod for the determination of fluoride in blood plasma and saliva. Calcif Tissue Res 23:225-228

27. Ekstrand J, Ehrnebo M, Boréus, LO 1978 Fluoride bioavailability after intravenous and oral administration: importance of renal clearance and urine flow. Clin Pharmacol Ther 23:329-337

28. Ekstrand J. Alvan G. Boréus L, Norlin A 1977 Pharmacokinetics of fluoride in man after single and multiple oral doses. Eur J Clin Pharmacol 12 : $311-317$

29. Ekstrand J. Ehrnebo M. Whitford GM, Järnberg PO 1980 Fluoride pharmacokinetics during acid-base balance changes in man. Eur $\mathrm{J}$ Clin Pharmacol $18: 189-194$

30. Ekstrand J. Spak C-J. Ehrnebo M 1982 Renal clearance of fluoride in a steady state condition in man: influence of urinary flow and $\mathrm{pH}$ changes by diet. Acta Pharmacol Toxicol 50:321-325

31. Schiffl H. Binswanger U 1980 Human urinary fluoride excretion as influenced by renal functional impairment. Nephron 26:69-72

32. Schiffl $\mathrm{H}$, Binswanger $U$ 1982 Renal handling of fluoride in healthy man. Renal Physiol 5:192-196

33. Järnberg P-O. Ekstrand J. Ehrnebo M 1983 Renal excretion of fluoride during water diuresis and induced urinary pH-changes in man. Toxicol Lett 18:141-

34. Spak C-J, Berg U. Ekstrand J 1985 Renal clearance of fluoride in children and adolescents. Pediatrics 75:575-579

35. Ericsson $Y$. Hellstrom I. Hofvander $Y 1972$ Pilot studies on the fluoride metabolism in infants on different feedings. Acta Paediat Scand 61:459-464

36. Hellstrom I 1976 Studies on fluoride distribution in infants and small children. Scand J Dent Res 84:119-136 